\section{(2) \\ BRAZIILIAN JOURNAL \\ OF MEDICAL AND BIOLOGICAL RESEARCH}

www.bjournal.com.br
ISSN 0100-879X

Volume 45 (3) 179-290 March 2012

BIOMIEDICAL SCIENCES

AND

CLINICAL INVESTIGATION

Braz J Med Biol Res, March 2012, Volume 45(3) 284-290

doi: $10.1590 / \mathrm{S} 0100-879 X 2012007500013$

Clinical features of patients with type 2 diabetes mellitus and hepatitis $\mathrm{C}$ infection

L.F. Greca, L.C. Pinto, D.R. Rados, L.H. Canani and J.L. Gross

The Brazilian Journal of Medical and Biological Research is partially financed by

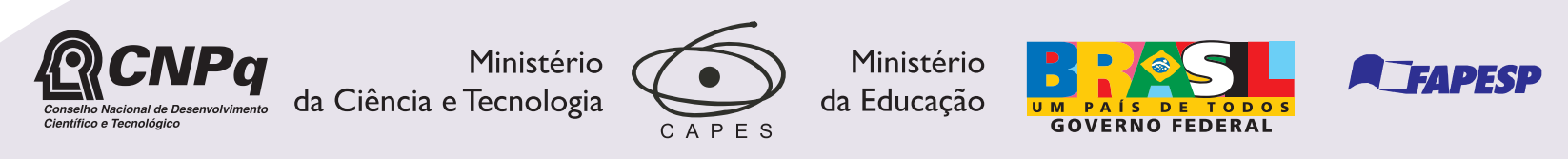

Institutional Sponsors

scielo
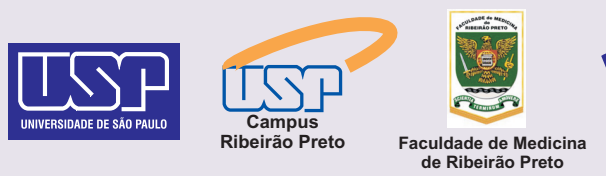

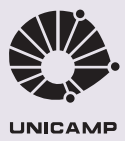

UNICAMP
Ф SHIMADZu

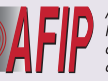

Associaçaco Associaçăo
Fundo
de Incentivo à Pesquisa 


\title{
Clinical features of patients with type 2 diabetes mellitus and hepatitis $\mathrm{C}$ infection
}

\author{
L.F. Greca, L.C. Pinto, D.R. Rados, L.H. Canani and J.L. Gross \\ Serviço de Endocrinologia, Hospital de Clínicas de Porto Alegre, \\ Universidade Federal do Rio Grande do Sul, Porto Alegre, RS, Brasil
}

\begin{abstract}
The objective of the present cross-sectional study was to assess the prevalence and the clinical and laboratory features of hepatitis $\mathrm{C}$ virus (HCV)-positive patients with type 2 diabetes mellitus (DM) attending either an outpatient clinic or hemodialysis units. Serologic-HCV testing was performed in 489 type 2 DM patients (303 outpatients and 186 on dialysis). A structured assessment of clinical, laboratory and DM-related complications was performed and the patients were then compared according to HCV infection status. Mean patient age was 60 years; HCV positivity (HCV+) was observed in 39 of 303 (12.9\%) outpatients and in 34 of $186(18.7 \%)$ dialysis patients. Among HCV+ patients, 32 were men (43.8\%). HCV+ patients had higher serum levels of aspartate aminotransferase ( $0.90 \pm 0.83$ vs $0.35 \pm 0.13 \mu \mathrm{Kat} / \mathrm{L})$, alanine aminotransferase $(0.88 \pm 0.93$ vs $0.38 \pm 0.19 \mu \mathrm{Kat} / \mathrm{L})$, gamma-glutamyl transferase $(1.57 \pm 2.52$ vs $0.62 \pm 0.87 \mu \mathrm{Kat} / \mathrm{L} ; \mathrm{P}<0.001)$, and serum iron (17.65 \pm 6.68 vs $14.96 \pm 4.72 \mu \mathrm{M} ; \mathrm{P}=0.011)$, and lower leukocyte and platelet counts $(\mathrm{P}=0.010$ and $\mathrm{P}<0.001$, respectively) than $\mathrm{HCV}$-negative (HCV-) patients. HCV+ dialysis patients had higher diastolic blood pressure than HCV-patients (87.5 \pm 6.7 vs $81.5 \pm 6.0 \mathrm{mmHg} ; \mathrm{P}=0.005$ ) and a lower prevalence of diabetic retinopathy (75 vs $92.7 \% ; \mathrm{P}=0.007$ ). In conclusion, our study showed that HCV is common among subjects with type $2 \mathrm{DM}$ but is not associated with a higher prevalence of chronic diabetic complications.
\end{abstract}

Key words: Type 2 diabetes; Hepatitis C; Dialysis

\section{Introduction}

Type 2 diabetes mellitus (DM) is a prevalent disease that affects $7.6 \%$ of the Brazilian population (1). It is linked to several chronic complications such as retinopathy, nephropathy, peripheral, and autonomic neuropathy, as well as to a high prevalence of cardiovascular disease (2).

Hepatitis $\mathrm{C}$ virus (HCV) infection is also a common disease worldwide, and its prevalence varies according to population, ranging from $0.6 \%$ among volunteer blood donors to $80 \%$ among intravenous drug users, with an estimated overall prevalence of $3 \%(3)$.

Since 1994, several groups have reported an association between HCV infection and type 2 DM (4-13). The prevalence of $\mathrm{HCV}$ infection among diabetic subjects ranges from 2 to $11.5 \%(12-14)$ and seems to be unrelated to hepatic fibrosis grade or to the presence of cirrhosis. HCV infection appears to precede the development of type 2 DM (10). Inflammatory cytokines such as tumor necrosis factor- $\alpha$ (TNF- $\alpha$ ), soluble TNF receptor 1 (sTNFR1), sTNFR2 and interleukin-6 (15), serum levels of ferritin (16), and adi- ponectin, an anti-inflammatory cytokine $(17,18)$, may be involved in its pathogenesis.

The presence of $\mathrm{HCV}$ infection in patients with DM may also increase the proportion of DM-related chronic complications. In fact, there are some reports showing that $\mathrm{HCV}$ infection is associated with an increased risk of developing diabetic nephropathy (18). Moreover, end-stage renal disease patients with type $2 \mathrm{DM}$ and positive $\mathrm{HCV}$ infection $(\mathrm{HCV}+)$ undergoing renal replacement therapy have a worse cumulative survival. However, these studies were conducted on selected populations of Afro-American (19) and Afro-Caribbean (20) patients, which may have influenced the results.

In view of these considerations, the objective of the present study was to analyze the frequency of HCV infection in a cohort of type 2 DM patients attending an outpatient clinic of a general hospital or dialysis units and to evaluate the clinical and laboratory features associated with HCV infection in these patients.

Correspondence: J.L. Gross, Serviço de Endocrinologia, Hospital de Clínicas de Porto Alegre, UFRGS, Rua Ramiro Barcelos, 2350, Prédio 12, 4ํandar, 90035-003 Porto Alegre, RS, Brasil. Fax: 55-51-2101-8777. E-mail: jorgegross@terra.com.br

Received March 14, 2011. Accepted October 6, 2011. Available online February 3, 2012. Published March 19, 2012. 


\section{Patients and Methods}

\section{Patients}

Across-sectional study was conducted on 303 consecutive patients with type $2 \mathrm{DM}$ attending the outpatient clinic of the Hospital de Clínicas de Porto Alegre from December 2005 to December 2007. We also analyzed 186 patients with type 2 DM from 3 hemodialysis units in Porto Alegre and surrounding areas. Type $2 \mathrm{DM}$ was defined as disease onset after 30 years of age, no previous episode of ketoacidosis or documented ketonuria, and treatment with insulin only 5 years after diagnosis.

Hospital de Clínicas de Porto Alegre's Ethics Committee approved this study, and written informed consent was obtained from all patients.

\section{Patient evaluation}

Patients underwent a standardized evaluation consisting of a questionnaire, physical examination, and laboratory tests. Weight and height were measured in patients without shoes and wearing light outdoor clothing and body mass index (BMI) was calculated [weight $(\mathrm{kg}) /$ height $(\mathrm{m})^{2}$ ]. Waist circumference at the narrowest point as viewed from the front and hip circumference at the widest point was also measured. Blood pressure (BP) was measured according to JNC 7 recommendations (21) in the left arm of the patient in a sitting position, after a 5 -min rest and using a mercury sphygmomanometer. The average of two office BP measurements was used for analysis. Hypertension was defined as systolic BP (SBP) $\geq 140 \mathrm{mmHg}$ and/or diastolic $\mathrm{BP}(\mathrm{DBP}) \geq 90 \mathrm{mmHg}$ on at least 2 occasions, or when the subject was using antihypertensive medication(s).

Urinary albumin excretion (UAE) was measured using two collection methods, according to their availability at the center: a 24-h timed urine collection or random spot sterile urine samples. The cutoff values used to define the stages of renal involvement followed the recommendations of the American Diabetes Association for timed urine collection. Subjects were classified as having normoalbuminuria if albumin in the collection was less than $20 \mu \mathrm{g} / \mathrm{min}$, microalbuminuria if the levels of albumin in the collection were greater than $20 \mu \mathrm{g} / \mathrm{min}$ but smaller than $200 \mu \mathrm{g} / \mathrm{min}$, and macroalbuminuria if the levels were greater than $200 \mu \mathrm{g} / \mathrm{min}$. For spot samples, urine concentration $(\mathrm{mg} / \mathrm{L})$ cutoffs were used as previously validated in our central laboratory (22) as follows: normoalbuminuria ( $<17 \mathrm{mg} / \mathrm{L})$, microalbuminuria (17-174 mg/L), and proteinuria (>174 mg/L).

An ophthalmologist performed direct fundoscopy, and diabetic retinopathy was classified as absent, nonproliferative or proliferative.

Coronary heart disease (CHD) was diagnosed as previously described (23). Briefly, CHD was established in the presence of angina or possible infarct according to the World Health Organization Cardiovascular Questionnaire and/or the presence of resting electrocardiogram abnor- malities (Minnesota Code Q and QS patterns [1.1-2, 1.3]; S-T junction [J] and segment depression [4.1-4]; T wave items [5.1-3], and complete left bundle block [7.1]) and/or the presence of perfusion abnormalities (fixed or variable) upon myocardial scintigraphy at rest and after dipyridamole administration. Intermittent claudication (WHO Cardiovascular Questionnaire (24)) and/or absence of a posterior tibial pulse upon clinical examination indicated peripheral vascular disease (PVD). Cerebrovascular disease was established on the basis of a history of stroke and/or presence of compatible findings.

Distal sensory neuropathy (DSN) was diagnosed based on the presence of typical symptoms or abnormal results in a 10-g Semmes-Weinstein monofilament sensory perception test at the hallux of each foot.

Information about HCV status was based on anti-HCV test, polymerase chain reaction (PCR) for HCV or hepatic biopsy and information about treatment was obtained from medical chart data, when available. If patients were positive in the anti-HCV test, they were evaluated by PCR for HCV. Given the small availability of the test during the study, most patients did not have data about genotype or viral load by the end of the study.

Data for dialysis patients were obtained only through medical chart review. Ultrasonography was not available for any patient at the time of the study.

\section{Laboratory methods}

Serological testing for anti-HCV and hepatitis B surface antigen (HBsAg) was done using a second-generation enzyme immunoassay (DiaSorin ${ }^{\odot}$, Italy). The anti-HCV test has a sensitivity of $100 \%$ and a diagnostic specificity of 99.8\%. PCR for HCV was performed by Imunoblot (RIBA, USA). Serum alanine aminotransferase (ALT) and aspartate aminotransferase (AST) were measured by the UV kinetic method (Roche ${ }^{\odot}$ Diagnostics, USA), and gamma-glutamyl transferase (GGT) was determined by a kinetic colorimetric method (HITACHI 911 Analyzer, Germany).

UAE was measured by immunoturbidimetry (Microalb, Ames Bayer ${ }^{\odot}$, USA; intra- and interassay coefficient variations of 4.5 and $11.0 \%$, respectively). Hemoglobin A1c was measured by HPLC (Merck-Hitachi $9100^{\circ}$, Germany; normal range 4-6\%) and fasting plasma glucose by the glucose-peroxidase colorimetric enzymatic method (Biodiagnóstica $^{\odot}$, Colombia). Creatinine was measured by the Jaffé method and the lipid profile by a colorimetric method. Sedimentation rate was measured by a kinetic and photometric automated method, and C-reactive protein (CRP) by nephelometry (Behring, Canada).

A complete blood count was obtained by light absorbance, impedance and flow cytometry. Serum iron, transferrin saturation and ferropexic capacity were measured by the ferrozin colorimetric method (Roche ${ }^{\complement}$ Diagnostics, Germany) and ferritin was measured by chemiluminescence (IMMULITE ${ }^{\circledR} 2000$, USA). 


\section{Statistical analysis}

The Student $t$-test or chi-square test was used to compare clinical and laboratory data. Quantitative variables not in a normal distribution were log transformed. A $P$ value of 0.05 was considered to be significant.

\section{Results}

\section{Prevalence}

Anti-HCV testing was positive in 73 of 489 patients (15\%) - 39 of $303(12.9 \%)$ outpatients and 34 of $186(18.27 \%)$ dialysis patients. Of the total 73 patients with both diabetes and positive HCV testing, 46 were newly diagnosed by the screening method and 27 had already been diagnosed. Of these, 3 had eliminated the virus spontaneously and 6 had been treated with interferon + ribavirin (only 1 eliminated the virus).

The main risk factor for HCV was blood transfusion before 1992 (16 patients), and no risk factor was identified in the remaining patients. Among the patients with an identifiable risk factor, possible HCV exposure had occurred on average 14.3 years before the diagnosis of DM. However, 4 of 23 patients had received a diagnosis of DM an average of 11.6 years before the possible exposure to HCV.

Six of the patients had been clinically diagnosed with cirrhosis (all of them were in Child's A stage), but only 4 patients had data about a liver biopsy in their medical chart.

\section{Outpatients}

Clinical and laboratory features. Clinical and laboratory features are shown in Table 1. There was no difference between $\mathrm{HCV}+$ and HCV-negative (HCV-) patients concerning age, age at diagnosis of DM, duration of DM, ethnicity, gender distribution, smoking status, family history of DM, or proportion with diagnosis of hypertension. SBP and DBP, BMI, waist circumference, glycemic control (fasting plasma glucose and A1C test), and lipid profile were also similar for the two groups. The use of statins and of an angiotensin-converting enzyme inhibitor (ACEI) was higher in the $\mathrm{HCV}$ - than in $\mathrm{HCV}+$ group, while the use of fibrates did not differ between groups. As expected, liver function tests (ALT, AST, and GGT) were higher in $\mathrm{HCV}+$ were $\mathrm{HCV}$ - or $\mathrm{HCV}+$. than in HCV- patients. Among patients with abnormal liver tests (>2.5 $x$ above the upper limit of normal, ULN) $40 \%$ were $\mathrm{HCV}+$, whereas only $11.2 \%$ of the patients with normal liver tests $(\leq 2.5 \times \mathrm{ULN})$ were $\mathrm{HCV}+$. The presence of abnormal liver tests is predictive of HCV infection, with an odds ratio of $5.31(95 \% \mathrm{Cl}=2.29-12.30)$. In addition, $8.3 \%$ of the patients without viral hepatitis (HCV- and HBsAg-) had abnormal liver tests (Table 2).

Platelet and leukocyte counts were lower in $\mathrm{HCV}+$ patients, while serum iron was higher. Ferritin tended to be higher, but the difference was not statistically significant. Hematocrit, total hemoglobin, ferropexic capacity, and transferrin saturation were similar for the two groups. Inflammatory markers such as CRP and sedimentation rate did not differ between groups (Table 2).

Chronic complications of diabetes. Diabetic retinopathy was present in $102(51.5 \%)$ of the HCV- and in 12 (35.3\%) of the $\mathrm{HCV}+$ patients $(\mathrm{P}=0.27$; Table 3$)$. Analysis of the severity of retinopathy (nonproliferative or proliferative) did not show any difference between $\mathrm{HCV}+$ and HCV-patients $(P=0.39)$.

Diabetic nephropathy was present in $52.7 \%$ of HCV-and in $48.8 \%$ of $\mathrm{HCV}+$ patients $(\mathrm{P}=0.640)$. The proportion of subjects with microalbuminuria or macroalbuminuria was

Table 1. Clinical features of type 2 diabetes mellitus outpatients and dialysis patients who

\begin{tabular}{|c|c|c|c|c|}
\hline & \multicolumn{2}{|c|}{ Outpatients } & \multicolumn{2}{|c|}{ Dialysis patients } \\
\hline & HCV- $(\mathrm{N}=226)$ & $\mathrm{HCV}+(\mathrm{N}=39)$ & HCV- $(\mathrm{N}=132)$ & $\mathrm{HCV}+(\mathrm{N}=34)$ \\
\hline Age (years) & $58.8 \pm 10.0$ & $61.0 \pm 11.5$ & $61.3 \pm 10.4$ & $58.9 \pm 10.4$ \\
\hline Women & $122(53.9)$ & $24(61.5)$ & $56(42.4)$ & $17(50)$ \\
\hline White & $160(70.8)$ & $29(74.3)$ & $79(59.8)$ & $19(55.9)$ \\
\hline BMI $\left(\mathrm{kg} / \mathrm{m}^{2}\right)$ & $30.2 \pm 5.2$ & $30.0 \pm 5.3$ & $25.8 \pm 6.0$ & $24.6 \pm 5.3$ \\
\hline DM duration (years) & $12.6 \pm 8.3$ & $12.0 \pm 9.0$ & $19.5 \pm 9.7$ & $18.0 \pm 10.5$ \\
\hline Hypertension ${ }^{+}$ & $104(90.4)$ & $33(84.6)$ & $34(94.4)$ & $9(100)$ \\
\hline $\mathrm{SBP}(\mathrm{mmHg})^{++}$ & $141 \pm 24.5$ & $138 \pm 20.3$ & $146.5 \pm 16$ & $156 \pm 14$ \\
\hline $\mathrm{DBP}(\mathrm{mmHg})^{++}$ & $84 \pm 14.5$ & $84 \pm 11.4$ & $81.5 \pm 6.0$ & $87.5 \pm 6.7^{*}$ \\
\hline \multicolumn{5}{|l|}{ Smoking } \\
\hline Current & $35(15.5)$ & $2(5.1)$ & $9(6.8)$ & $2(5.9)$ \\
\hline Ex & $73(32.3)$ & $16(41.0)$ & $55(41.6)$ & $19(55.9)$ \\
\hline \multicolumn{5}{|l|}{ Family history } \\
\hline Mother & $92(40.7)$ & $19(48.7)$ & $48(36.7)$ & $13(38.2)$ \\
\hline Father & $45(19.9)$ & $7(17.9)$ & $30(22.7)$ & $8(23.5)$ \\
\hline Statin use $^{+++}$ & $107(47.4)$ & $7(19.4)^{\#}$ & $17(23.3)$ & $7(29.2)$ \\
\hline Fibrate use & $15(6.6)$ & $0(0)$ & $1(0.8)$ & $0(0)$ \\
\hline ACEl use & $124(54.9)$ & $14(35.9)$ & $67(50.8)$ & $17(50)$ \\
\hline
\end{tabular}

Data are reported as means \pm SD or number (\%) of patients. BMI = body mass index; DM = diabetes mellitus; $\mathrm{SBP}=$ systolic blood pressure; $\mathrm{DBP}=$ diastolic blood pressure; $\mathrm{ACEI}=$ angiotensin-converting enzyme inhibitor. ${ }^{+} \mathrm{N}=115$ for HCV- outpatients; $\mathrm{N}=45$ for dialysis patients (36 HCV- and $9 \mathrm{HCV}+) ;{ }^{++} \mathrm{N}=58$ for dialysis patients $(47 \mathrm{HCV}$ - and $11 \mathrm{HCV}+) ;{ }^{++} \mathrm{N}$ = 97 for dialysis patients $(73 \mathrm{HCV}$ - and $24 \mathrm{HCV}+)$. ${ }^{*} \mathrm{P}<0.05$ compared to HCV- (Student $t-$ test). ${ }^{\mathrm{P}}<0.05$ compared to HCV- (chi-square test). 
Table 2. Laboratory features of type 2 diabetes mellitus outpatients and dialysis patients who were HCV- or $\mathrm{HCV}+$.

\begin{tabular}{|c|c|c|c|c|}
\hline & \multicolumn{2}{|c|}{ Outpatients } & \multicolumn{2}{|c|}{ Dyalisis patients } \\
\hline & HCV- $(\mathrm{N}=250)$ & $\mathrm{HCV}+(\mathrm{N}=39)$ & HCV- $(\mathrm{N}=140)$ & $\mathrm{HCV}+(\mathrm{N}=34)$ \\
\hline Fasting glucose (mM) & $9.39 \pm 3.94$ & $8.78 \pm 3.11$ & $9.92 \pm 5.28$ & $9.16 \pm 4.22$ \\
\hline A1c test $(\%)$ & $8.0 \pm 1.9$ & $8.0 \pm 2.1$ & $6.3 \pm 2.5$ & $7.0 \pm 2.6$ \\
\hline Total cholesterol (mM) & $4.78 \pm 1.14$ & $4.47 \pm 1.28$ & $4.45 \pm 1.01$ & $4.63 \pm 1.60$ \\
\hline HDL cholesterol (mM) & $1.29 \pm 0.36$ & $1.37 \pm 0.41$ & $1.11 \pm 0.44$ & $1.14 \pm 0.62$ \\
\hline LDL cholesterol (mM) & $2.61 \pm 0.98$ & $2.43 \pm 1.08$ & $2.38 \pm 0.93$ & $2.40 \pm 1.39$ \\
\hline Triglycerides (mM) & $1.67(0.30-18.84)$ & $1.13(0.47-3.79)$ & $1.87(0.61-9.90)$ & $1.96(0.55-5.68)$ \\
\hline Serum creatinine $(\mu \mathrm{M})$ & $114.92 \pm 141.44$ & $114.92 \pm 167.96$ & $663.00 \pm 247.52$ & $698.36 \pm 221.00$ \\
\hline AST (GOT) ( $\mu \mathrm{Kat} / \mathrm{L})$ & $0.35 \pm 0.13$ & $0.90 \pm 0.83^{*}$ & - & - \\
\hline ALT (GPT) $(\mu \mathrm{Kat} / \mathrm{L})$ & $0.38 \pm 0.19$ & $0.88 \pm 0.93^{*}$ & - & - \\
\hline GGT $(\mu \mathrm{Kat} / \mathrm{L})$ & $0.62 \pm 0.87$ & $1.57 \pm 2.52^{*}$ & - & - \\
\hline Hematocrit (\%) & $39.4 \pm 4.5$ & $39.1 \pm 5.5$ & $32.2 \pm 7.1$ & $32.5 \pm 5.8$ \\
\hline Hemoglobin level (g/L) & $130 \pm 24$ & $128 \pm 20$ & $109 \pm 23$ & $112 \pm 17$ \\
\hline Leukocytes (cells/ $\mu \mathrm{L}$ ) & $7831 \pm 3987$ & $6146 \pm 2132^{*}$ & - & - \\
\hline Platelets $(\mathrm{U} / \mu \mathrm{L})$ & $244550 \pm 66347$ & $171482 \pm 68187^{*}$ & - & - \\
\hline Serum iron $(\mu \mathrm{M})^{+}$ & $14.96 \pm 4.72$ & $17.65 \pm 6.68^{*}$ & - & - \\
\hline Ferritin $(\mu \mathrm{g} / \mathrm{L})^{+}$ & $213.9 \pm 182$ & $287 \pm 316$ & - & - \\
\hline Ferropexic capacity $(\mu \mathrm{M})^{+}$ & $58.87 \pm 14.00$ & $62.01 \pm 9.65$ & - & - \\
\hline Transferrin saturation $(\%)^{+}$ & $26.3 \pm 9.3$ & $29.5 \pm 12.0$ & - & - \\
\hline C-reactive protein $(\mathrm{mg} / \mathrm{L})^{+}$ & $5.8 \pm 11.2$ & $3.6 \pm 5.0$ & - & - \\
\hline Sedimentation rate $(\mathrm{mm} / \mathrm{h})^{+}$ & $19.8 \pm 18.3$ & $20.8 \pm 18.5$ & - & - \\
\hline
\end{tabular}

Data are reported as means \pm SD. Triglyceride levels are reported as median (range). A1c test $=$ glycated hemoglobin; $\mathrm{HDL}=$ high-density lipoprotein; $\mathrm{LDL}=$ low-density lipoprotein; AST = aspartate aminotransferase (GOT = glutamic-oxaloacetic transaminase); $A L T$ = alanine aminotransferase (GPT = glutamic-pyruvic transaminase); GGT = gamma-glutamyl transferase. ${ }^{+} \mathrm{N}=215$ for HCV- and 39 for HCV+ outpatients. ${ }^{*} \mathrm{P}<$ 0.05 compared to HCV- (Student $t$-test).

Table 3. Chronic complications of type 2 diabetes mellitus outpatients and dialysis patients who were HCV- or $\mathrm{HCV}+$.

\begin{tabular}{|c|c|c|c|c|}
\hline & \multicolumn{2}{|c|}{ Outpatients } & \multicolumn{2}{|c|}{ Dialysis patients } \\
\hline & HCV- $(\mathrm{N}=198)$ & $\mathrm{HCV}+(\mathrm{N}=34)$ & $\operatorname{HCV}-(\mathrm{N}=124)$ & $\mathrm{HCV}+(\mathrm{N}=29)$ \\
\hline Diabetic retinopathy (Yes) & $102(51.5)$ & $12(35.3)$ & $115(92.7)$ & $22(75.9)^{*}$ \\
\hline Nonproliferative & $49(24.7)$ & $10(28.6)$ & $42(33.9)$ & $7(24.1)$ \\
\hline Proliferative & $52(26.3)$ & $5(14.3)$ & $70(56.5)$ & $16(55.2)$ \\
\hline Nephropathy (Yes) ${ }^{+}$ & $136(52.7)$ & $16(48.8)$ & & \\
\hline Microalbuminuria $^{+}$ & $82(31.8)$ & $11(32.5)$ & & \\
\hline Macroalbuminuria $^{+}$ & $28(10.9)$ & $4(10)$ & & \\
\hline Dialysis $^{+}$ & $26(10.1)$ & $3(7.5)$ & & \\
\hline Distal sensory neuropathy $(Y e s)^{++}$ & $45(22.5)$ & $10(31)$ & $33(51.6)$ & $8(44.4)$ \\
\hline Peripheral vascular disease (Yes) & $48(24.2)$ & $30(87.5)$ & $59(47.4)$ & $11(37)$ \\
\hline Coronary heart disease (Yes) & $83(41.9)$ & $14(41.7)$ & $89(72)$ & $17(58.3)$ \\
\hline Cerebrovascular disease (Yes) & $19(9.5)$ & $3(9.7)$ & $16(13)$ & $2(6.1)$ \\
\hline
\end{tabular}

Data are reported as number (\%) of patients. ${ }^{+} \mathrm{N}=258$ for HCV- and 34 for $\mathrm{HCV}+$ outpatients; ${ }^{++} \mathrm{N}=82$ for dialysis patients (64 HCV- and $18 \mathrm{HCV}+)$. ${ }^{*} \mathrm{P}<0.05$ compared to HCV- (chi-square test). 
also similar for the two groups.

The prevalence of DSN, PVD, CHD, and cerebrovascular disease was similar in both groups (Table 3 ).

\section{Patients on dialysis}

Clinical and laboratory features. The clinical and laboratory features of these patients are shown in Table 2. There was no difference between $\mathrm{HCV}+$ and $\mathrm{HCV}$ - patients regarding age, age at diagnosis of DM, duration of DM, ethnicity, gender distribution, smoking status, family history of DM, or diagnosis of hypertension. SBP, BMI, waist circumference, glycemic control (fasting plasma glucose and A1c test) and lipid profile were also similar for the two groups. The use of statins, fibrates and ACEI did not differ between the $\mathrm{HCV}$ - and $\mathrm{HCV}+$ groups, although no $\mathrm{HCV}+$ patients were using fibrates. DBP was significantly higher in the $\mathrm{HCV}+$ group than in the HCV-group. Hematocrit and hemoglobin levels were similar for the two groups.

Chronic complications of diabetes. The prevalence of diabetic retinopathy was significantly higher in HCV$(92.7 \%)$ than in $\mathrm{HCV}+(75.9 \%)$ patients, but the severity of retinopathy was similar (Table 3). The prevalence of DSN, PVD, CHD, and cerebrovascular disease was also similar in both groups, as shown in Table 3 .

\section{Discussion}

The present study observed a higher frequency of $\mathrm{HCV}$ infection in patients with type 2 DM than would be expected amongst the general population $(13,20,25)$, and $\mathrm{HCV}$ infection seemed to precede the development of DM, as the average time between possible exposure to $\mathrm{HCV}$ and DM diagnosis was 14.3 years. However, HCV+ DM patients did not present a higher prevalence of chronic complications of DM.

An increased prevalence of HCV infection has been reported by other investigators $(12,13)$ and the rate observed in the present study (15\%) is very similar to the $11.5 \%$ rate reported by Simo et al. (13) in a sample of white patients with type 1 and type 2 DM. The association of type 2 DM and HCV infection might be due to an increased susceptibility of type $2 \mathrm{DM}$ patients to more frequent hospitalizations and daily use of syringes (10). Alternatively, HCV infection might predispose patients to the development of type 2 DM, by interfering in lipid metabolism, inhibiting signaling pathways in the liver, increasing hepatic steatosis and then inducing insulin resistance $(5,15,26,27)$. However, the exact mechanism of insulin resistance induced by HCV remains to be clarified.

Our study did not confirm previous reports of a distinct DM phenotype associated with HCV infection (13,28-30), with $\mathrm{HCV}+$ diabetic patients being leaner and presenting lower total and LDL cholesterol levels than HCV- diabetic patients. The finding that our patients had similar LDL and total cholesterol levels may be partially explained by the more frequent use of statins by HCV- outpatients.

Family history was listed in some studies as a risk factor for the development of HCV-associated type 2 DM (29,31), but in our study, the presence of a family history of DM did not differ between groups.

The only clinical features in our study that might be helpful to identify $\mathrm{HCV}+$ patients among diabetic patients were abnormal liver enzymes. Although we did not evaluate the presence of hepatic steatosis, which is part of metabolic syndrome, and therefore commonly found in diabetic patients, we think that screening for HCV infection should be done in all DM patients with abnormal liver enzymes, as done in the general population, since they are predictive of $\mathrm{HCV}$ infection. Abnormal liver tests in patients without viral hepatitis might be due to non-alcoholic steatohepatitis or other hepatopathies.

Inflammatory markers such as CRP, sedimentation rate and ferritin levels, that were also thought to be a clue for identifying $\mathrm{HCV}+$ patients, were similar in our study, despite the idea of an inflammatory link between the two diseases. In further studies, other inflammatory markers, such as adipocytokines, should be assessed, as they seem to play a role in insulin resistance (32).

The presence of HCV infection does not seem to change the development of chronic complications of DM, since their prevalence were similar for $\mathrm{HCV}+$ and $\mathrm{HCV}$ - patients. It was thought that $\mathrm{HCV}+$ patients could have a higher prevalence of proteinuric nephropathy since the most frequent extrahepatic manifestation of $\mathrm{HCV}$ is mixed cryoglobulinemia (33). We did not measure serum cryoglobulins nor did we perform a renal biopsy since the prevalence of proteinuric nephropathy was the same in both $\mathrm{HCV}$ - and $\mathrm{HCV}+$ patients. In fact, the prevalence of retinopathy was lower among $\mathrm{HCV}+$ patients in the dialysis group. We speculate that this could be due to a survival bias since it has been reported that $\mathrm{HCV}+$ patients with type $2 \mathrm{DM}$ undergoing renal replacement therapy have a worse cumulative survival (19). Perhaps the less severe cases, which are the ones who survive, presented less retinopathy. In addition to the inability to perform a renal biopsy to assess the particular cause of nephropathy, another weakness of our study is that our patients did not have an ultrasonography available to help in the evaluation of liver damage. However, the main results of the study would not be altered if ultrasonography data were available because there were no significant clinical differences between groups.

Our findings confirm the hypothesis of a study performed in an Italian population (34), in which HCV+ did not worsen vascular complications in DM patients. That study discussed whether abnormalities induced by hepatopathy (lower cholesterol levels, lower platelet counting) could protect the cardiovascular system against atherosclerosis, while another Japanese study (35) found HCV antibodies to be an independent risk factor for atherosclerosis. In the present study, we did not assess atherosclerosis itself, but evaluated its clini- 
cal outcomes (coronary artery disease and peripheral vascular disease), and their prevalence did not differ between $\mathrm{HCV}+$ and HCV-, in either the outpatient or in dialysis group.

$\mathrm{HCV}$ infection was found to be more common in patients with type $2 \mathrm{DM}$ than among the general population, and therefore, we suggest that these patients be regularly tested for HCV infection, especially those with abnormal liver tests. However, a cost-benefit study is necessary to assess the real gain for the patients. This approach is in agreement with the current literature. Gutiérrez-Grobe et al. (36) suggested, recently, that all patients with hepatitis $C$ should be screened for type 2 diabetes given the increasing prevalence of both conditions worldwide and the pro-inflammatory state, which

\section{References}

1. Malerbi DA, Franco LJ. Multicenter study of the prevalence of diabetes mellitus and impaired glucose tolerance in the urban Brazilian population aged 30-69 yr. The Brazilian Cooperative Group on the Study of Diabetes Prevalence. Diabetes Care 1992; 15: 1509-1516.

2. Kannel WB, McGee DL. Diabetes and cardiovascular disease. The Framingham study. JAMA 1979; 241: 20352038.

3. Yen T, Keeffe EB, Ahmed A. The epidemiology of hepatitis C virus infection. J Clin Gastroenterol 2003; 36: 47-53.

4. Mason AL, Lau JY, Hoang N, Qian K, Alexander GJ, Xu L, et al. Association of diabetes mellitus and chronic hepatitis C virus infection. Hepatology 1999; 29: 328-333.

5. Caronia S, Taylor K, Pagliaro L, Carr C, Palazzo U, Petrik $\mathrm{J}$, et al. Further evidence for an association between noninsulin-dependent diabetes mellitus and chronic hepatitis $C$ virus infection. Hepatology 1999; 30: 1059-1063.

6. Knobler H, Schattner A. Association of hepatitis $\mathrm{C}$ and diabetes mellitus. Ann Intern Med 2001; 135: 141.

7. AIDosary AA, Ramji AS, Elliott TG, Sirrs SM, Thompson DM, Erb SR, et al. Post-liver transplantation diabetes mellitus: an association with hepatitis C. Liver Transpl 2002; 8: 356361.

8. Hui JM, Sud A, Farrell GC, Bandara P, Byth K, Kench JG, et al. Insulin resistance is associated with chronic hepatitis $\mathrm{C}$ virus infection and fibrosis progression. Gastroenterology 2003; 125: 1695-1704.

9. Knobler H, Schihmanter R, Zifroni A, Fenakel G, Schattner A. Increased risk of type 2 diabetes in noncirrhotic patients with chronic hepatitis C virus infection. Mayo Clin Proc 2000; 75: 355-359.

10. Mehta SH, Brancati FL, Strathdee SA, Pankow JS, Netski D, Coresh J, et al. Hepatitis $C$ virus infection and incident type 2 diabetes. Hepatology 2003; 38: 50-56.

11. Knobler $\mathrm{H}$, Schattner A. TNF-\{alpha\}, chronic hepatitis $\mathrm{C}$ and diabetes: a novel triad. QJM 2005; 98: 1-6.

12. Parolin MB, Rea R, Vargas RM, de Almeida AC, Baldanzi GR, Lopes RW. [Prevalence of hepatitis C infection in patients with type 2 diabetes mellitus]. Arq Gastroenterol 2006; 43: $77-80$.

13. Simo R, Hernandez C, Genesca J, Jardi R, Mesa J. High prevalence of hepatitis $\mathrm{C}$ virus infection in diabetic patients. links both conditions $(15-18,37,38)$.

In our study, the presence of HCV infection was not associated with a higher prevalence of chronic complications of DM. A prospective study would be important to evaluate if the presence of HCV would predispose to the development of chronic complications and influence the mortality rate and cause of death.

\section{Acknowledgments}

Research partially supported by PRONEX, CNPq and Fundo de Incentivo à Pesquisa (FIPE) do Hospital de Clínicas de Porto Alegre.
Diabetes Care 1996; 19: 998-1000.

14. Cadranel JF, Di Martino V, Lambrey G, Mourlhon C, Nalet $B$, Anciaux ML, et al. Prevalence of hepatitis $C$ infection and risk factors in hospitalized diabetic patients: results of a cross-sectional study. Eur J Gastroenterol Hepatol 2008; 20: 829-836.

15. Lecube A, Hernandez C, Genesca J, Simo R. Proinflammatory cytokines, insulin resistance, and insulin secretion in chronic hepatitis C patients: A case-control study. Diabetes Care 2006; 29: 1096-1101.

16. Lecube A, Hernandez C, Genesca J, Esteban JI, Jardi R, Garcia L, et al. Diabetes is the main factor accounting for the high ferritin levels detected in chronic hepatitis $C$ virus infection. Diabetes Care 2004; 27: 2669-2675.

17. Roden M. Mechanisms of disease: hepatic steatosis in type 2 diabetes - pathogenesis and clinical relevance. Nat Clin Pract Endocrinol Metab 2006; 2: 335-348.

18. Pagano C, Soardo G, Esposito W, Fallo F, Basan L, Donnini $\mathrm{D}$, et al. Plasma adiponectin is decreased in nonalcoholic fatty liver disease. Eur J Endocrinol 2005; 152: 113-118.

19. Crook ED, Penumalee S, Gavini B, Filippova K. Hepatitis $\mathrm{C}$ is a predictor of poorer renal survival in diabetic patients. Diabetes Care 2005; 28: 2187-2191.

20. Gray H, Wreghitt T, Stratton IM, Alexander GJ, Turner RC, O'Rahilly S. High prevalence of hepatitis $C$ infection in AfroCaribbean patients with type 2 diabetes and abnormal liver function tests. Diabet Med 1995; 12: 244-249.

21. Chobanian AV, Bakris GL, Black HR, Cushman WC, Green LA, Izzo JL Jr, et al. The Seventh Report of the Joint National Committee on Prevention, Detection, Evaluation, and Treatment of High Blood Pressure: the JNC 7 report. JAMA 2003; 289: 2560-2572.

22. Zelmanovitz T, Gross JL, Oliveira JR, Paggi A, Tatsch M, Azevedo MJ. The receiver operating characteristics curve in the evaluation of a random urine specimen as a screening test for diabetic nephropathy. Diabetes Care 1997; 20: 516-519.

23. Costa LA, Canani LH, Lisboa HR, Tres GS, Gross JL. Aggregation of features of the metabolic syndrome is associated with increased prevalence of chronic complications in Type 2 diabetes. Diabet Med 2004; 21: 252-255.

24. Rose GABH, Gillum RF, Prineas RJ. Cardiovascular survey 
methods. 2nd edn. Geneva: WHO Monograph Ser.; 1982.

25. Chen HF, Li CY, Chen P, See TT, Lee HY. Seroprevalence of hepatitis B and $\mathrm{C}$ in type 2 diabetic patients. J Chin Med Assoc 2006; 69: 146-152.

26. Oliveira BR, Magalhaes O, Furlanetto TW, Bertoluci MC. Increased insulin resistance and hyperinsulinemia in patients with type 2 diabetes and chronic hepatitis C. Diabetes Res Clin Pract 2008; 79: e11-e12.

27. Shaheen M, Echeverry D, Oblad MG, Montoya MI, Teklehaimanot S, Akhtar AJ. Hepatitis C, metabolic syndrome, and inflammatory markers: results from the Third National Health and Nutrition Examination Survey [NHANES III]. Diabetes Res Clin Pract 2007; 75: 320-326.

28. Antonelli A, Ferri C, Fallahi P, Sebastiani M, Nesti C, Barani $\mathrm{L}$, et al. Type 2 diabetes in hepatitis C-related mixed cryoglobulinaemia patients. Rheumatology 2004; 43: 238-240.

29. Behrendt CE, Ruiz RB. Hyperglycemia among persons with hepatitis C: not the classical diabetic phenotype. Diabetes Res Clin Pract 2006; 71: 68-74.

30. Antonelli A, Ferri C, Fallahi P, Pampana A, Ferrari SM, Goglia F, et al. Hepatitis C virus infection: evidence for an association with type 2 diabetes. Diabetes Care 2005; 28: 2548-2550.

31. Zein CO, Levy C, Basu A, Zein NN. Chronic hepatitis C and type II diabetes mellitus: a prospective cross-sectional study. Am J Gastroenterol 2005; 100: 48-55.

32. Hui JM, Hodge A, Farrell GC, Kench JG, Kriketos A, George $\mathrm{J}$. Beyond insulin resistance in NASH: TNF-alpha or adiponectin? Hepatology 2004; 40: 46-54.

33. Zignego AL, Ferri C, Pileri SA, Caini P, Bianchi FB. Extrahepatic manifestations of Hepatitis $C$ Virus infection: a general overview and guidelines for a clinical approach. Dig Liver Dis 2007; 39: 2-17.

34. Bianchi G, Marchesini G, Zoli M, Bugianesi E, Fabbri A, Pisi E. Prognostic significance of diabetes in patients with cirrhosis. Hepatology 1994; 20: 119-125.

35. Fukui M, Kitagawa Y, Nakamura N, Yoshikawa T. Hepatitis $\mathrm{C}$ virus and atherosclerosis in patients with type 2 diabetes. JAMA 2003; 289: 1245-1246.

36. Gutiérrez-Grobe Y, Ponciano-Rodríguez G, Méndez-Sánchez N. Viral hepatitis infection and insulin resistance: a review of the pathophysiological mechanisms. Salud Publica Mex 2011; 53 (Suppl 1): S46-S51.

37. Minm S. Hepatitis C virus, diabetes and steatosis: clinical evidence in favor of a linkage and role of genotypes. Dig Dis 2010; 28: 280-284.

38. Serfaty L, Capeau J. Hepatitis C, insulin and diabetes: clinical and pathogenical data. Liver Int 2009; 29: 13-25. 